\title{
The sleeping brain regulates to the edge of chaos
}

Moira L Steyn-Ross ${ }^{1 *}$, Alistair Steyn-Ross ${ }^{1}$, Jamie W Sleigh ${ }^{2}$

From The Twenty Third Annual Computational Neuroscience Meeting: CNS*2014

Québec City, Canada. 26-31 July 2014

One of the most intriguing ideas in complexity theory is the notion that some systems can organize dynamically to a point critically poised between order and disorder, hovering at the so-called "edge of chaos". It has been proposed that the computational performance of neural networks is optimized when close to the order-disorder phase transition. In this presentation we explore the novel hypothesis that the human brain may be operating at the

(a) Wake

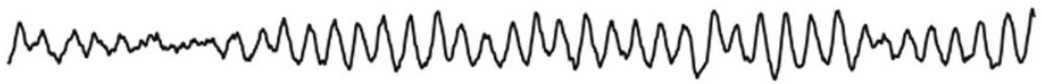

(b) NREM stage-1

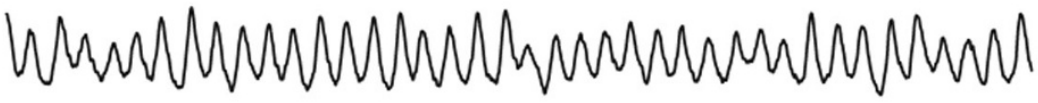

(c) NREM stage-2

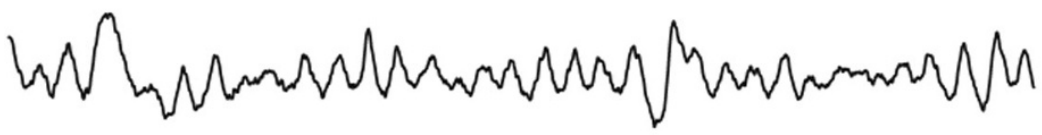

(d) NREM stage-4

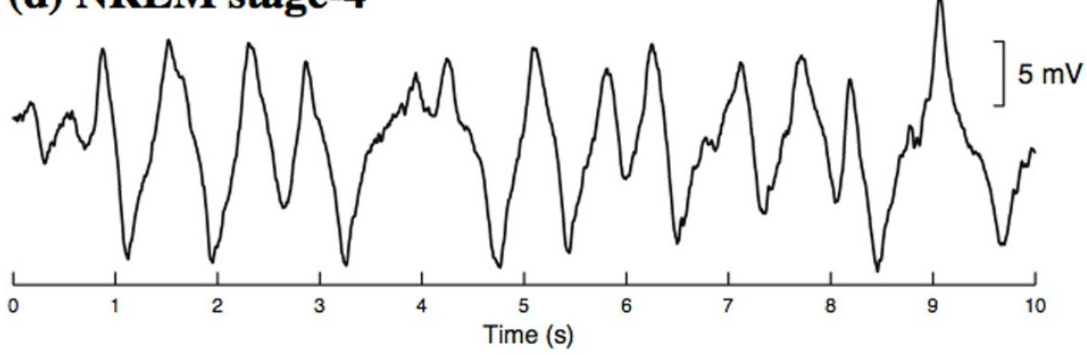

Figure 1 Model-generated sleep electrocorticograms for descent from wake to deep NREM. Model predictions are the excitatory soma voltage recorded at one point on a $120 \times 120$ cortical grid after filtering with a $0.5-\mathrm{Hz}$ high-pass filter.

\footnotetext{
* Correspondence: msr@waikato.ac.nz

'School of Engineering, University of Waikato, Hamilton 3240, New Zealand

Full list of author information is available at the end of the article
}

(C) 2014 Steyn-Ross et al; licensee BioMed Central Ltd. This is an Open Access article distributed under the terms of the Creative Commons Attribution License (http://creativecommons.org/licenses/by/4.0), which permits unrestricted use, distribution, and reproduction in any medium, provided the original work is properly cited. The Creative Commons Public Domain Dedication waiver (http://creativecommons.org/publicdomain/zero/1.0/) applies to the data made available in this article, unless otherwise stated. 
edge of chaos during slow-wave sleep (SWS), the deepest phase of NREM (non-rapid-eye-movement) sleep.

We build on an existing continuum model of the cortex [1] to incorporate known changes in specific neurotransmitter concentrations-GABA increase with simultaneous acetylcholine (ACh) decrease-during descent from wake into natural SWS [2]. The GABA boost is modeled as an anesthetic-like prolongation of the inhibitory postsyaptic potential (IPSP) paired with a restriction of gap-junction connectivity, while ACh suppression reduces resting cell voltage but enhances excitatory synaptic efficiency. Our model is able to produce a plausible sequence of time-series for EEG progression through the stages of NREM sleep (see Figure 1).

These sleep-induced neurotransmitter changes can have profound effects on cortical stability: alterations in inhibitory gap-junction connectivity controls a patternforming Turing instability, and manipulations of IPSP duration can lead to Hopf temporal oscillations which, in a pathological limit, can lead to whole-of-cortex seizure. We argue that normal brain function requires a balance between Turing and Hopf instabilities, and that descent into deep sleep entails a rebalancing in favor the Hopf instability. Model simulations predict that the spatiotemporal patterns for NREM sleep stages- 1 to -4 are chaotic, showing exponential trajectory divergence from closely similar starting conditions. In contrast, the seizure state is highly ordered and non-chaotic. Since most sleepers do not proceed to seizure, we posit the existence of a protective mechanism that regulates the naturally sleeping brain so that it remains close to-but does not cross -the disorder/order boundary during deepest sleep.

There is clinical evidence that high cortical activity is associated with closure of gap-junctions [3]. This has motivated a learning rule that regulates the gap-junction conductivity based on the spatial covariance of inhibitory firing-rate activity across the two-dimensional cortical grid. We find that this rule enables the cortex to regulate its slow-wave dynamics from chaotic to marginally-ordered, and that regulation failure typically leads to seizure onset.

\footnotetext{
Authors' details

${ }^{1}$ School of Engineering, University of Waikato, Hamilton 3240, New Zealand. ${ }^{2}$ Waikato Clinical School, University of Auckland, Hamilton 3240, New Zealand.

Published: 21 July 2014

\section{References}

1. Steyn-Ross ML, Steyn-Ross DA, Sleigh JW: Interacting Turing-Hopf Instabilities Drive Symmetry-Breaking Transitions in a Mean-Field Model of the Cortex: A Mechanism for the Slow Oscillation. Phys Rev X 2013, 3(2):021005

2. Vanini G, Lydic R, Baghdoyan HA: GABA-to-ACh ratio in basal forebrain and cerebral cortex varies significantly during sleep. Sleep 2012, 35(10):1325-1334.
}

3. Palacios-Prado N, Hoge G, Marandykina A, et al: Intracellular magnesiumdependent modulation of gap junction channels formed by neuronal connexin36. J Neurosci 2013, 33(11):4741-4753.

doi:10.1186/1471-2202-15-S1-O19

Cite this article as: Steyn-Ross et al:: The sleeping brain regulates to the edge of chaos. BMC Neuroscience 2014 15(Suppl 1):019.

\section{Submit your next manuscript to BioMed Central and take full advantage of:}

- Convenient online submission

- Thorough peer review

- No space constraints or color figure charges

- Immediate publication on acceptance

- Inclusion in PubMed, CAS, Scopus and Google Scholar

- Research which is freely available for redistribution

Submit your manuscript at www.biomedcentral.com/submit 